\title{
LOCUS OF CONTROL AND STUDENT ACHIEVEMENT
}

\begin{abstract}
Locus of control is one of the personality characteristics possessed by humans. Locus of control can be divided into two, namely internal locus of control and external locus of control. Locus of control is a predictor of several other variables, such as learning achievement. The purpose of this study was to determine the relationship of locus of control with learning achievement. This research uses descriptive and correlational methods. The instrument filling is done online by using the google form application considering the increasing spread of COVID-19. Finally, as many as 36 students participated in filling this instrument. In this study, researchers used the Rotters Internal-External Locus of Control (IE Scale) inventory consisting of 29 items, of which there were 6 filler items, so that the total number of items that could be processed was 23 items, while to see learning achievement using the Grade Point Average (GPA) that researchers get from the Academic Information System (SIAKAD). Research findings show that locus of control has a strong negative relationship with student learning achievement. We advise students to have an internal locus of control while continuing to believe in God; The counselor is expected to be able to arrange an intervention program for students who have an external locus of control and have low learning achievement.
\end{abstract}

Keywords: self control, learning, industrial revolution 4.0

\begin{abstract}
Abstrak. Locus of control merupakan salah satu karakteristik kepribadian yang dimiliki manusia. Locus of control dibedakan menjadi dua, yakni internal locus of control dan eksternal locus of control. Locus of control merupakan prediktor beberapa variabel lainnya, seperti prestasi belajar. Tujuan penelitian ini untuk mengetahui bubungan locus of control dengan prestasi belajar. Penelitian ini menggunakan metode deskriptif dan korelasional. Pengisian instrumen dilakukan secara online dengan menggunakan aplikasi google form mengingat penyebaran COVID-19 yang semakin meningkat. Akbirnya sebanyak 36 mahasiswa berpartisipasi dalam pengisian instrumen ini. Dalam penelitian ini, peneliti menggunakan Inventory Rotters Internal-External Locus of Control (I-E Scale) yang terdiri dari 29 item, di mana terdapat 6 filler item, sebingga jumlah total item yang dapat diolah sebanyak 23 item, sedangkan untuk melihat prestasi belajar menggunakan indeks prestasi kumulatif (IPK) yang peneliti dapatkan dari Sistem Informasi Akademike (SLAKAD). Temuan penelitian menunjukean bahwa locus of control memiliki bubungan negatif yang kuat dengan prestasi belajar mahasiswa. Kami menyarankan kepada mahasiswa untuk memiliki internal locus of control dengan tetap percaya kepada Tuhan; kepada konselor diharapkan dapat menyusun program intervensi terhadap mahasiswa yang memiliki eksternal locus of control dan memiliki prestasi belajar yang rendah.
\end{abstract}

Kata kunci: locus of control; prestasi belajar; mahasiswa

\section{INTRODUCTION}

Locus of control is one's belief in being able to control events in life. Locus of control is divided into two forms namely internal locus of control and external locus of control(Rotter, 1990). 
Internal locus of control refers to the extent to which a person expects that the reinforcement or outcome of their behavior depends on their own behavior or personal characteristics, and the external locus of control to the extent that someone expects that reinforcement or results are a function of chance, luck, or fate, in under the control of another's, or unexpected power (Rotter, 1966).

Until now there is still debate about whether the internal locus of control or external locus of control, even if seen from its characteristics the internal locus of control is much better. But the question is, does someone who feels he can determine the direction of life without external influences (such as God), can be said to be better than someone who always expects God's help? Studies on locus of control which are then associated with religious affiliation or the level of religiosity have been carried out with various results (Geist \& Bangham, 1980; Knott et al., 2015; Salehi et al., 2007; Shrauger \& Silverman, 1971; Eko Sujadi \& Meditamar, 2020). Besides religious / religiosity factors, locus of control is also influenced by various other factors such as gender, age, position in office, social demographics, economic status, family and ethnicity (Angelova, 2016; Bulut Serin et al., 2010; Cohen \& Azaiza, 2007; Lal, 1985; Mamlin et al., 2001; Shannak \& Al-Taher, 2012; E Sujadi, 2018; Eko Sujadi \& Meditamar, 2020; Virmozelova, 2011; Weintraub et al., 2015; Wenzel, 1993). Various demographic and special characteristics are predicted to be able to determine the orientation of the locus of control used by a person, internal or external locus of control.

The study of student locus of control in tertiary institutions is also quite interesting to study. The diverse student conditions allow students to have a locus of control that is also diverse, especially if we look at the character of each student. These diverse conditions sometimes hamper the learning process, especially those with an external orientation locus of control. The conditions are generally found as they do not do the task, not active in the learning process, do not care about the learning material, do not have achievement motivation, low motivation to learn, and others. Actually some universities have tried to overcome this problem but counselors are still confused about the right program design (Eko Sujadi, 2018).

Internal orientation of internal locus of control has a correlation with good learning achievement, and vice versa. This is proven through several previous studies (Bar-Tal \& BarZohar, 1977; Fini \& Yousefzadeh, 2011; Ghasemzadeh \& saadat, 2011; Stipek, 1980; E Sujadi, 2019; Turner, 1978). Learning achievement is very important for every student. Good learning achievement is a realization of the factor of self-effort (internal locus of control), whereas individuals who do not have confidence in the internal factors of self tend to be oriented towards external locus of control. 
Based on the background of the problem, the researcher wants to know the relationship between locus of control and student learning achievement; the researcher will also classify the orientation of the locus of control which most influences the high or low student achievement. The results of this study are expected to be the basis for counseling service interventions from counselors to students, especially those who have low learning achievements due to locus of control orientation tends to be external.

\section{METHODS}

This research uses a quantitative approach with descriptive and correlational methods. The instrument filling is done online by using the google form application considering the increasing spread of COVID-19. Finally, as many as 36 students participated in the filling of this instrument. In this study, researchers used the Rotters Internal-External Locus of Control (IE Scale) inventory that contained 29 items, of which there were 6 filler items, so that the total number of items that could be scored was 23 items, whereas to see learning achievements using a Grade Point Average (GPA) that researchers get from the Academic Information System (SIAKAD). Determination of assessment criteria using special categorization norms. To find out the relationship between the independent variable and the dependent variable, analyzed using spearman rank order analysis techniques. Data analysis using SPSS 22 for windows program.

\section{RESULTS}

A total of 36 participants participated to fill out the questionnaire that researchers distributed online. The purpose of this study was to determine the relationship between locus of control and student learning achievement. A description of the student locus of control is presented in the following table:

Table 1: Average Locus of Control Students

\begin{tabular}{ccccc}
\hline $\mathrm{N}$ & The lowest score & The highest score & Total Score & The mean \\
\hline 36 & 6 & 16 & 394 & 10.94 \\
\hline
\end{tabular}

Table 1 noted that of the 36 participants, the lowest score was 6 and the highest score was 16 , and the average score was 10.94. From this data it can be understood that the locus of control of participants tends to be in the internal category because it is below the median value.

Furthermore, the frequency and percentage details of each locus of control category can be seen in table 2: 
Table 2: Frequency and percentage of Participus Locus of Control

\begin{tabular}{cccc}
\hline No & Category & Frequency & Percentage \\
\hline 1 & Internal & 23 & $63.89 \%$ \\
\hline 2 & External & 13 & $36.11 \%$ \\
\hline \multicolumn{2}{c}{ Total } & 38 & $100 \%$ \\
\hline
\end{tabular}

Seen in table 4, participants in the internal locus of control category were 23 students $(63.89 \%)$ and 13 students were in the external locus of control category (36.11\%).

Testing the hypothesis in this study using the Spearman rank order analysis technique. This technique is chosen because the data is not normal. Results of data analysis can be seen in table 3:

Table 3: Statistical Test Results by Using the Spearman Rank Order

\begin{tabular}{|c|c|c|c|c|}
\hline & & & LoC & GPA \\
\hline \multirow{6}{*}{ Spearman's rho } & \multirow{3}{*}{ LoC } & Correlation Coefficient & 1,000 & $-.425 * *$ \\
\hline & & Sig. (2-tailed) & & .010 \\
\hline & & $\mathrm{N}$ & 36 & 36 \\
\hline & \multirow{3}{*}{ GPA } & Correlation Coefficient & $-.425 * *$ & 1,000 \\
\hline & & Sig. (2-tailed) & .010 & \\
\hline & & $\mathrm{N}$ & 36 & 36 \\
\hline
\end{tabular}

**. Correlation is significant at the 0.01 level (2-tailed).

Table 3 illustrates that there is a strong negative relationship between locus of control and learning achievement $(.010<.05)$. This indicates that the more external locus of control, student achievement is low, conversely the more internal locus of control, student achievement tends to be good.

\section{DISCUSSION}

The results showed that the locus of control of students tended to be in the internal category, although the difference was not far from the middle value. Furthermore, testing the hypothesis proves that there is a strong negative relationship between locus of control and learning achievement $(.010<.05)$. This indicates that the more external locus of control, student achievement is low, conversely the more internal locus of control, student achievement tends to be good.

As has been explained that the locus of control is one's belief in being able to control events in life. Locus of control is divided into two forms namely internal locus of control and external locus of control (Rotter, 1990). Internal locus of control refers to the extent to which a person expects that the reinforcement or outcome of their behavior depends on their own behavior or personal characteristics, and the external locus of control to the extent that someone 
expects that reinforcement or results are a function of chance, luck, or fate, in under the control of another's, or unexpected power (Rotter, 1966).

The findings of this study are consistent with previous research. A study revealed that student learning performance with high internal locus of control tends to be more proactive and effective during the learning process. On the other hand, those who have external locus of control are more passive and reactive during this period (Abid et al., 2016). The same results were expressed through other studies that there was a significant relationship between locus of control and learning achievement (Mohamed et al., 2018). Other studies have shown that locus of control is a strong predictor for student achievement(Dada \& Fagbemi, 2018; E Sujadi, 2018; Eko Sujadi et al., 2016). In particular there is also the influence of locus of control on students' mathematics learning achievement (Septiani, 2017).

A good locus of control needs to be owned by all students because it can improve their learning achievement. As has been explained that there is still much debate about the locus of control that is important to have, whether internal or external. But having internal locus of control characteristics by not releasing the deity obligation is much better.

\section{CONCLUSION}

These findings reveal that participants' locus of control is in the internal category. Then based on hypothesis testing, found a strong negative relationship between locus of control with student learning achievement. The more internal the locus of control of students, the higher the learning achievement, conversely the more external the lower the student learning outcomes. This indicates that students need to have an internal locus of control without relinquishing deity obligations.

Researchers provide advice to students to continue to be able to form personality characteristics that support success; lecturers to be able to instill character values to students, not only to focus on cognitive aspects; then to the counselor to be able to formulate a counseling service program with a focus on locus of control.

\section{REFERENCE}

Abid, M. ., Kanwal, S., Nasir, M. A. ., Iqbal, S., \& Huda, N. . (2016). The Effect of Locus of Control on Academic Performance of the Students at Tertiary level. International Review of Management and Business Research, 5(3), 860-869.

Angelova, N. (2016). Locus of control and its relationship with some social-demographic factors. 
Psychological Thought, 9, 248-258. https://doi.org/10.5964/psyct.v9i2.179

Bar-Tal, D., \& Bar-Zohar, Y. (1977). The relationship between perception of locus of control and academic achievement: Review and some educational implications. Contemporary Educational Psychology, 2(2), 181-199. https://doi.org/https://doi.org/10.1016/0361-476X(77)90020-0

Bulut Serin, N., Serin, O., \& Şahin Kıralp, F. S. (2010). Factors affecting the locus of control of the university students. Procedia - Social and Behavioral Sciences, 2, 449-452. https://doi.org/10.1016/j.sbspro.2010.03.041

Cohen, M., \& Azaiza, F. (2007). Health-promoting behaviors and health locus of control from a multicultural perspective. Ethnicity \& Disease, 17(4), 636-642.

Dada, O. ., \& Fagbemi, O. . (2018). Influence of Emotional Intelligence and Locus of Control on Academic Achievement of Underachieving High Ability Students. Journal for the Education of Gifted Young, 6(2), 14-22.

Fini, A. A. S., \& Yousefzadeh, M. (2011). Survey on Relationship of Achievement Motivation, Locus of Control and Academic Achievement in High School Students of Bandar Abbas (Iran). Procedia - Social and Behavioral Sciences, 30, 866-870. https://doi.org/https://doi.org/10.1016/j.sbspro.2011.10.168

Geist, C. R., \& Bangham, W. R. (1980). Locus of Control and Religious Affiliation. Psychological Reports, 47(3_suppl), 1281-1282. https://doi.org/10.2466/pr0.1980.47.3f.1281

Ghasemzadeh, A., \& saadat, M. (2011). Locus of Control in Iranian University Student and Its Relationship with Academic Achievement. Procedia - Social and Behavioral Sciences, 30, 24912496. https://doi.org/https://doi.org/10.1016/j.sbspro.2011.10.486

Knott, C., Roth, D., Huang, J., \& Clark, E. (2015). Gender Differences in the Roles of Religion and Locus of Control on Alcohol Use and Smoking Among African Americans. Journal of Studies on Alcohol and Drugs, 76, 482-492. https://doi.org/10.15288/jsad.2015.76.482

Lal, B. (1985). Relationship Between Sex Differences in Locus of Control and Job Performance in Library Organizations. Annals of Library Science and Documentation, 31(3-4), 76-79.

Mamlin, N., Harris, K. R., \& Case, L. P. (2001). A methodological analysis of research on locus of control and learning disabilities: Rethinking a common assumption. The Journal of Special Education, 34(4), 214-225. https://doi.org/10.1177/002246690103400404

Mohamed, A. ., Mohammed, A. ., \& Ahmed, H. . (2018). Relation Between Locus of Control and Academic Achievement of Nursing Students at Damanhour University. IOSR Journal of Nursing and Health Science, 7(5), 1-13.

Rotter, J. B. (1966). Generalized expectancies for internal versus external control of reinforcement. In Psychological Monographs: General and Applied (Vol. 80, Issue 1, pp. 1-28). American Psychological Association. https://doi.org/10.1037/h0092976

Rotter, J. B. (1990). Internal Versus External Control of Reinforcement. American Psychologist, 45(4), 489-493.

Salehi, L., Solimanzadeh, L., Yazdi, S., \& Abbaszadeh, A. (2007). The Relationship between Religious Beliefs and Locus of Control with Mental Health. The Journal of Qazvin Univ of Med. Sci, 11(1), 50-55.

Septiani, Y. (2017). Pengaruh Locus Of Control terhadap Prestasi Belajar Matematika. JKPM Jurnal Kajian Pendidikan Matematika), 2, 118. https://doi.org/10.30998/jkpm.v2i1.1898

Shannak, R., \& Al-Taher, A. (2012). Factors affecting Work Locus of Control: An Analytical and Comparative Study. Jordan Journal of Business Administration, 8, 373-389.

Shrauger, J. S., \& Silverman, R. E. (1971). The Relationship of Religious Background and Participation to Locus of Control. Journal for the Scientific Study of Religion, 10(1), 11-16. https://doi.org/10.2307/1385313

Stipek, D. (1980). A causal analysis of the relationship between locus of control and academic achievement in first grade. Contemporary Educational Psychology, 5(1), 90-99. https://doi.org/https://doi.org/10.1016/0361-476X(80)90029-6

Sujadi, E. (2018). Perbedaan Locus of Control ditinjau dari Etnis. Jurnal Bimbingan Dan Konseling 
Terapan, 2(2), 128-138. https://doi.org/10.30598/jbkt.v2i2.371

Sujadi, E. (2019). Penerapan Play Therapy dengan Menggunakan Permainan Tradisional untuk Meningkatkan Keterampilan Sosio Emosional. Jurnal Bimbingan Dan Konseling Terapan, 3(1), 14-24. https://doi.org/https://doi.org/10.30598/jbkt.v3i1.892

Sujadi, Eko. (2018). Kode Etik Profesi Konseling Serta Permasalahan dalam Penerapannya. Tarbawi: Jurnal Ilmu Pendidikan, 14(2), 69-77. https://doi.org/10.32939/tarbawi.v14i2.298

Sujadi, Eko, \& Meditamar, M. O. (2020). Perbedaan Locus of Control ditinjau dari Perspektif Agama pada Siswa SMA. Analitika: Jurnal Magister Psikologi UMA, 12(1), 44-54. https://doi.org/http://dx.doi.org/analitika.v11i1.3506

Sujadi, Eko, Yusuf, A. M., \& Marjohan, M. (2016). Hubungan antara Locus Of Control dan Efektivitas Komunikasi antar Pribadi dengan Problem Focused Coping. Konselor, 5(1), 2531. https://doi.org/https://doi.org/10.24036/02016516490-0-00

Turner, R. R. (1978). Locus of control, academic achievement, and Follow Through in Appalachia. Contemporary Educational Psychology, 3(4), 367-375. https://doi.org/https://doi.org/10.1016/0361-476X(78)90039-5

Virmozelova, N. (2011). Age and Gender-Based Differences in The Locus of Control. The Tenth International Conference Applied Psychology and Social Practice.

Weintraub, M., Mamani, A., \& Tawfik, S. (2015). The Interplay Among Locus Of Control, SubClinical Psychotic Symptoms and Psychological Well-Being in Whites and Ethnic Minorities. Revista Interamericana de Psicologia, 49(3), 413-424.

Wenzel, S. L. (1993). Gender, Ethnic Group, and Homelessness as Predictors of Locus of Control Among Job Training Participants. The Journal of Social Psychology, 133(4), 495-505. https://doi.org/10.1080/00224545.1993.9712174 